Volume-V, Issue-02, July-December, 2010

\title{
Labor Unrest and Bangladesh Labor Act 2006: A Study on Ready Made Garment Factories in Gazipur
}

\author{
MUSTAFA KAMAL $^{1}$ \\ MOHAMMED MASUM BILLAH ${ }^{2}$ \\ SANJIDA HOSSAIN ${ }^{3}$
}

\begin{abstract}
The Readymade garment (RMG) industry of Bangladesh has become the backbone of the national economy. It is the highest foreign exchange earner, it employs largest number of people and it generates vibration for other sectors. Despite the impressive performance, the RMG industry has several problems especially in its labor management practices. As a result, a lot of turmoil and disputes often rock the industry. The empirical evidence implies that labor law of the country has not been put into practice appropriately in the RMG industry. Proper and satisfactory implementation of labor law can eradicate the disputes and stop the commotions in the industry. In this study an attempt has been made to find out the relation between implementation of Bangladesh Labor Act 2006 and labor unrest. Seven major factors have been considered which are closely related to labor unrest. The study reveals that employees' wages and payment is the most significantly correlated factor to labor unrest.
\end{abstract}

\section{INTRODUCTION}

The term "garment" is used interchangeably with "apparel" and "clothing". "Garment" includes readymade woven garments as well as knitwear and hosiery. The products of the garments industry are very diverse, ranging from industrial work-wear basic shirt. The concept of "textile complex" or "textile chain" includes the ginning of fiber, spinning yarn, weaving fabrics and operations like dyeing, processing, printing, finishing the fiber and finally making the Readymade Garment

1 Professor, Department of Business Administration, Northern University

Bangladesh, Dhaka.

2 Assistant Professor, Department of Business Administration, Northern University

Bangladesh, Dhaka.

3 Senior Lecturer, Department of Business Administration, Northern University

Bangladesh, Dhaka. 
(RMG). The final product is garment ( M. Monjur Morshed, 2007). There are about 5000 readymade garment factories in Bangladesh, out of which 2100 factories are in Dhaka city and 860 are in Gazipur (According to BGMEA).

\section{Significance of RMG sector in Bangladesh}

The RMG sector has become the lifeline of Bangladeshi economy creating opportunities for jobs, income and exports. More than 10 million people, directly or indirectly, depend for their livelihood on this industry, which accounts for $40 \%$ of industrial employment. This very dynamic sector has become the main source of direct and indirect employment as well as of foreign exchange earnings (World Bank, 2006). The little small-scale industry that started its journey in the late 1970s has now become the backbone of the economy of the country. This industry alone contributes about $75 \%$ of the total exports. In the last financial year the total export volume of the RMG sector was more than $\$ 9.5$ billion. In terms of GDP, RMG's contribution is highly remarkable; it has become $13 \%$ of GDP which was only about 3\% in 1991(Ahmed and Hussain, 2006). Bangladeshi RMG industry has got a considerable share of the international markets. In 2006 Bangladesh became the 4th largest supplier of garment products in Europe. From 2004 to 2005 Bangladesh's share in US market increased from $2.42 \%$ to $2.69 \%$.

\section{Objectives of the study}

The main purpose of the study is to examine the relationship between labor unrest and the implementation of Bangladesh Labor Act 2006 in ready made garment units located in Gazipur, Bangladesh. The specific objectives are:-

(i) To examine the relationship between labor unrest and the application of Bangladesh Labor Act 2006.

(ii) To rank the factors of labour unrest with regard to Bangladesh Labor Act 2006.

(iii) To suggest some policy measures for planners and decision makers.

\section{LITERATURE REVIEW}

The RMG industry is a low-technology and labor-intensive industry. Being labor-surplus economy Bangladesh always enjoy low wages. With regard to pricies, Bangladesh can beat most of its competitors. Prices are related to the cost of production which in case of apparel marketing is greatly determined by the labor costs. The pressure of the unemployed labor force and the very low standard of living allow the garment wages in Bangladesh to be kept at a level that is one of the lowest among competing countries. That Bangladesh has a tremendous labor cost 
advantage can be seen by looking at the comparative hourly wages. Three factors have been primarily responsible for the lower labor cost in the garment industry compared to most other industries in Bangladesh (Mondal 2003).

First, the garment industry is characterized by a predominance of female workers who are prepared to accept lower wages than their male counterparts due to their opportunity cost of time. Second, the minimum wage fixed by the government has been lower for the garment industry compared to other industries. Third, garment entrepreneurs have succeeded in reducing labor costs by generally depriving workers of "decent" working conditions.

\section{The declining mode of RMG}

The downtrend in RMG sector, the mainstay of Bangladeshi export earnings, was reflected in the number of orders received during the period between December and March of the last fiscal, the time-period marked by political instability followed by massive labor unrest. During the review quarter, the economy came under considerable strains caused by higher costs of petroleum products, widespread agitations in the readymade garment sector and inflationary pressure though increased remittances and higher export earnings provided a favorable perspective.

The trade balance recorded a lower deficit of US\$ 90 million in July of FY07 compared to the deficit of \$116 million in July of FY06 (MCCI at The Daily Star, November 3, 2006.). The improvement in the trade balance occurred due to a higher relative growth of exports than import payments. Real GDP growth this year is estimated at 6.5 percent or nearly 20 percent better than last year, that is, the industry, manufacturing and service sectors are growing rapidly. There are indeed remarkable achievements, but those are not enough. Many estimates that sustained growth of seven to nine percent or more will be needed if Bangladesh hopes to raise the standard of living of its people significantly. Achieving that pace of growth will not be easy. Already, the Bangladeshi economy is under stress from high fuel and commodity prices and the financial burden caused by the under-pricing of energy products.

\section{Labor unrest in RMG sector}

In 1994 the minimum wage for a worker in the garment sector was 930 taka per month. Later, in 1997, the government refixed the minimum wage as 1550 taka per month (Elyus Rahman, 2006). However, the garment factory owners did not recognize this. The garment sector workers demanded that the owners recognize the minimum wage. They also demanded the establishment of a minimum wage board. 
In July 2001, the government declared a minimum wage structure for the private sector workers fixing 1350 taka as the minimum monthly salary, but the employers rejected the proposal of the Government. A member of the federation moved to the High Court and the High Court declared the government order illegal on technical grounds. (Elyus Rahman, 2006)

Now the garment factory workers have been getting a paltry sixty US cents per day, whereas the factory owners are getting richer day by day. They are building ultra modern houses in the smarter areas of the city and their children go to Europe and America for higher education. The garment workers have to work 10 to 12 hours a day, seven days a week, but are paid no overtime (Elyus Rahman, 2006). The garment workers demonstrated for an adjustment to the minimum wage, safe working condition, weekly holiday and an end to harassment. Very often, the workers were sacked without reasonable ground and notice or compensation as per the provisions of labor law. For this very reason the spontaneous, unprecedented protest was observed.

\section{Bangladesh Labor Act 2006}

Bangladesh Labor Act 2006 was passed by the parliament with effect from October 11, 2006. This new labor law has repealed 27 existing labor laws including Factories Act 1965, Payment of wages Act 1936, Shops and Establishments Act 1965, maternity benefit Act 1939, Industrial Relations Ordinance,1969, Employment of labor (S.O) Act 1965 etc. The following major factors from Bangladesh Labor Act, 2006 are taken into consideration for this study:

\section{(i) Conditions of service and employment}

It includes conditions of employment, classification of workers, letters of appointment and identity card, service book, form of service book, entries in the service book, register of workers and supply of tickets and cards. (Section 3-9, Bangladesh labor Act 2006)

\section{(ii) Health and Hygiene}

The Act describes the terms and conditions of cleanliness, ventilation and temperature, dust and fume, disposal of waste and effluents, overcrowding, lighting, drinking water, latrines and urinals, etc. (Section 51-59, Bangladesh labor Act 2006)

\section{(iii) Safety and Health}

It includes safety of the building and machinery, precaution in case of fire, fencing of machinery, work on or near machinery in motion, cranes and other lifting 
machinery, hoists and lifts, floors, stairs and means of access, etc. (Section 61-72, Bangladesh labor Act, 2006)

\section{(iv)Working hours and leave}

It describes the rules and regulation of daily hours, interval for rest or meal, weekly hours, weekly holiday, compensatory weekly holiday, spread over, night shift, extra allowances for overtime, casual leave, sick leave, annual leave with wages, festival holidays, etc. (Section 100-118, Bangladesh labor Act 2006)

\section{(v) Wages and payment}

It contains special definition of wages, responsibility for payment of wages, fixation of wage-periods, time of payment of wages, wages to be paid in current coin or currency notes, deductions for absence from duty, etc. (Section 120-126, Bangladesh labor Act 2006)

\section{(vi) Trade unions and industrial relations, disputes}

It narrates the rules and regulation of special definition of worker, trade unions of workers and employers, collective bargaining agent, participation committee, industrial disputes, lockout and strike, etc. (Section 175-211, Bangladesh labor Act 2006)

\section{(vii) Penalty and procedure}

It shows the penalty for non-compliance of labor court's order, penalty for employment of child and adolescent, penalty for unfair labor practices, penalty for illegal strike or lock out, penalty for taking part in or instigating go-slow, penalty for general offences by workers, penalty for other offences, etc. (Section 283-307, Bangladesh labor Law 2006)

Based on the above mentioned literature it assumed that most of the labor unrest occurred due to lack of proper implementation of Bangladesh labor Act 2006. Now the authors go for exploratory research to find out the reasons for labor unrest considering Bangladesh labor Act 2006, because labor unrest is a major problem for the growth and sustain of Ready Garment Factories.

\section{METHODOLOGY}

A structure questionnaire was prepared based on major provisions of Bangladesh Labor Law 2006 and other relevant literature survey, consulting various documents, such as, office-order; annual reports, employee profile, employee data base prepared by human resource department, newspapers, and journals. Interview technique was used with structured questionnaire for collection of primary data. The 
judgmental sampling procedure was used to select the sample units from different workers of different garment factories who were willing to respond to the questionnaire. Total number of respondents were seventy selected from 7 different garment factories in the Gazipur district. The draft questionnaire was tested with 5 garments workers to find out whether the questionnaire was understandable to them or if any changes and amendments were necessary. The questionnaire consists of 50 questions. Questions are designed in a five point Likert scale to find out the causes of labor unrest with the help of workers' rights according to Bangladesh labor law act 2006. Five point Likert type scale has been used in the questionnaire to measure workers' opinions about the implementation of worker rights by the company. 5 for strongly agree, 4 for agree, 3 for neutral, 2 for disagree and 1 for strongly disagree have been given in order to analyze data. (Luthans, 2002; Anon., 2003). To test the conditions of service and employment, six questions were asked in the questionnaire. Eight questions were asked to test health and hygiene, seven questions to test safety and health, six questions to test working hours and leave, six questions to test wages and payment, eight questions to test trade unions and industrial relations, three questions to test management and worker relations, and six questions to test labor unrest. To test the hypothesis, Pearson's product moment correlation analysis and multivariate analysis were used. The statistical computer package SPSS version 11.5 was utilized to analyze the data.

TABLE 1

\section{TYPE OF RESPONDENTS}

\begin{tabular}{lc}
\hline & Type of Respondents \\
\hline Type of Respondent & Number of Respondents \\
Loader & 72 \\
Painter & 10 \\
Sewing operator & 14 \\
Sewing helper & 6 \\
Iron man & 4 \\
Packer & 2 \\
Cutter & 2 \\
Patent and design operator & 6 \\
Quality control operator & 7 \\
Quality control helper & 70 \\
Total & \\
\hline
\end{tabular}




\section{Model}

The authors have used the labor unrest as the dependent variable and the worker rights permitted by Bangladesh labor Act 2006 are the independent variable like service and employment, health and hygiene, safety and health, working hours and leave, wages and payment, trade unions and industrial relations, management and worker relations, and labor unrest. The authors have run the OLS regression model to determine the significant reasons for labor unrest.

The basic model for the study was therefore as follows:

$$
\mathrm{U}=\alpha+\beta_{1} \mathrm{X}_{1}+\beta_{2} \mathrm{X}_{2}+\beta_{3} \mathrm{X}_{3}+\beta_{4} \mathrm{X}_{4}+\beta_{5} \mathrm{X}_{5}+\beta_{6} \mathrm{X}_{6}+\beta_{7} \mathrm{X}_{7}+e
$$

Where, $\mathrm{LU}=$ Labor unrest

$$
\mathrm{X}_{1}=\text { Service and employment }
$$$$
\mathrm{X}_{2}=\text { Health and hygiene }
$$$$
\mathrm{X}_{3}=\text { Safety and health }
$$$$
\mathrm{X}_{4}=\text { Working hours and leave }
$$$$
\mathrm{X}_{5}=\text { Wages and payment }
$$

$\mathrm{X}_{6}=$ Trade unions and industrial relations (management and worker relation)

$$
\mathrm{X}_{7}=\text { Penalty and procedure. }
$$

And $\alpha$ is constant and $\beta_{1,} \beta_{2,} \beta_{3,} \beta_{4,} \beta_{5,} \beta_{6,} \beta_{7}$ are coefficients to estimate, and $e$ is the error term, which the authors assumed as NIL for this research.

\section{Hypothesis}

Null Hypothesis

$\mathrm{H}_{1} 0$ : There is no relationship between labor unrest and the implementation of workers' rights on the basis of Bangladesh labor Act 2006.

$\mathrm{H}_{1} 0: \beta_{1}=\beta_{2}=\beta_{3}=------=\beta_{k}=0$ (Here, $\beta=$ regression coefficient)

Alternative Hypothesis $\mathrm{H}_{1} \mathrm{a}$ : There is a relationship between labor unrest and the implementation of workers' rights on the basis of Bangladesh labor Act 2006.

$\mathrm{H}_{1} \mathrm{a}$ : At least one $\beta$ is not zero.

\section{EMPIRICAL FINDINGS AND ANALYSIS}

Out of 70 respondents from different garments factories 52 are female and 18 are male. The respondents have been selected from seven garment factories in the Gazipur district of Bangladesh. 


\section{TABLE 2 \\ NAME OF THE GARMENT FACTORIES SELECTED FOR RESEARCH}

\begin{tabular}{c|l|c}
\hline $\begin{array}{c}\text { Sl. } \\
\text { No. }\end{array}$ & \multicolumn{1}{|c}{ Name of the Garment factories } & No of Participants ( Garment workers) \\
\hline 01 & Mascow Garments Ltd & 10 \\
02 & Bondage Fashion Ltd. & 10 \\
03 & Tanaz Fashion Ltd. & 10 \\
04 & Meem Garments & 10 \\
05 & R R Garments . & 10 \\
06 & Nippon Garments Industries Ltd. & 10 \\
07 & Mondol Garments & 10 \\
& Total No. of Respondents & 70 \\
\hline
\end{tabular}

Source: Field Survey August-December, 2009

\section{Descriptive Analysis}

Employees express their opinion in likert scale on whether working place is over crowded and harmful for health. Out of 70 employees, $14 \%$ employees strongly agreed, $54 \%$ employees simply agreed and 32\% employees demonstrated neutrally.

Figure 1: Working Place Over Crowded and Harmful for Health.

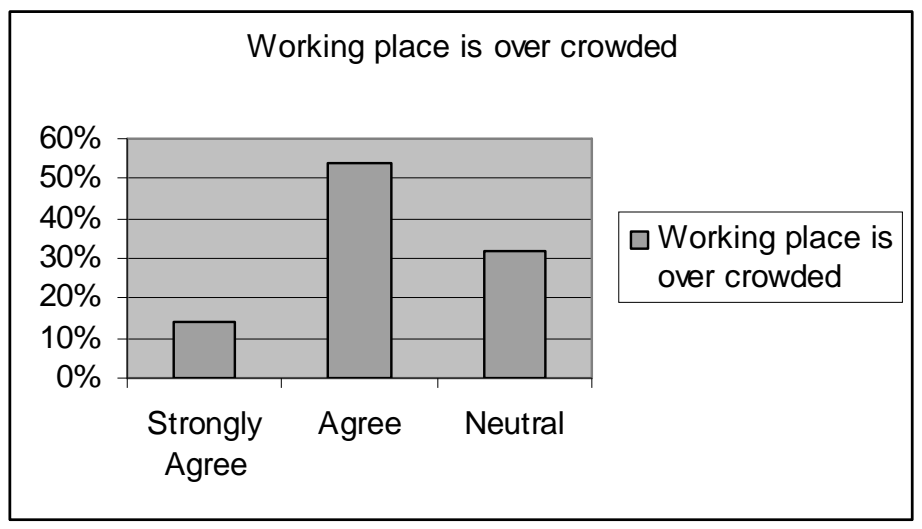

Source: Field Survey August-December, 2009

The garment workers opined whether company's building and machinery are risky for safety. It was found that $57 \%$ agreed, $30 \%$ disagreed and $13 \%$ strongly disagreed. 
Figure 2: Whether Company's Building and Machinery are Risk for Safety

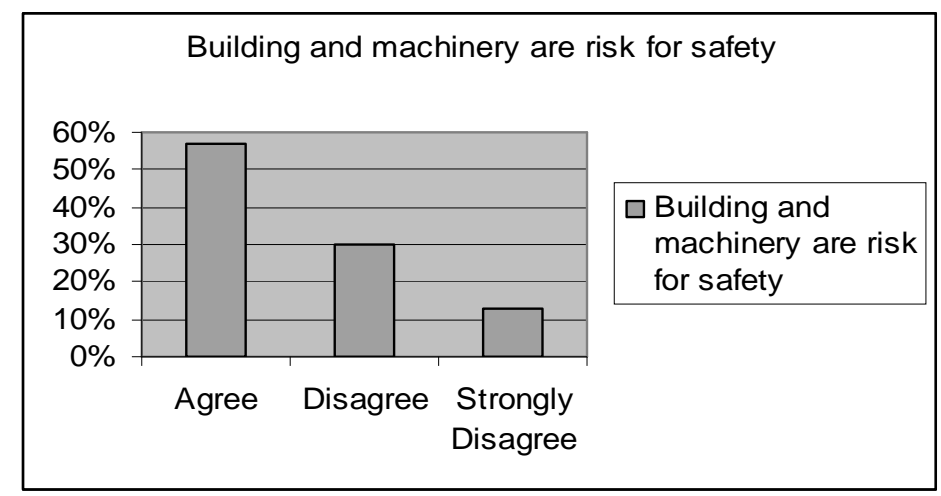

Source: Field Survey August-December, 2009

Employees were asked whether the factory has sufficient number of fire extinguishers and fire fighting instruments. $67 \%$ strongly agreed and $33 \%$ workers demonstrated neutrally. Every garment factory has fire extinguishers but not sufficient in number. And the truth is that most of the workers do not know how to operate this machinery.

Figure 3: Whether the Factory Has Sufficient Number of Fire Extinguisher and Fire Fighting Instrument

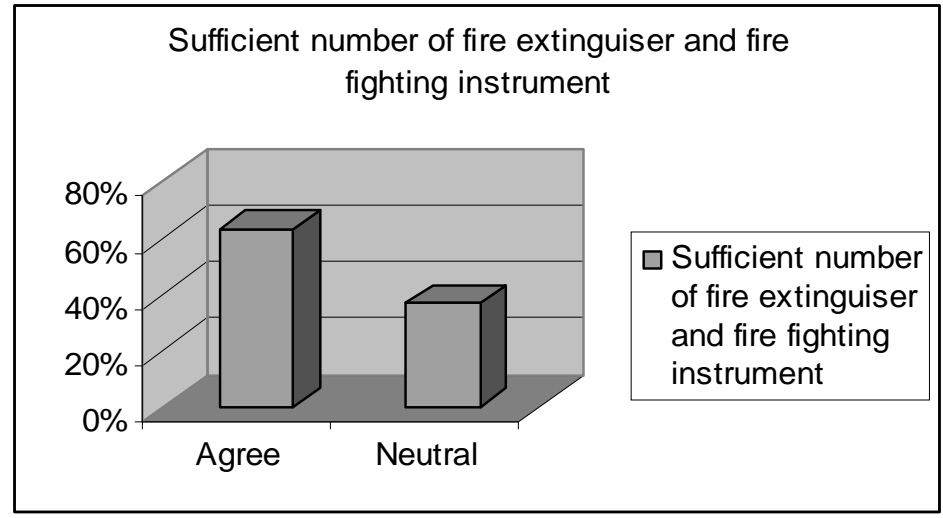

Source: Field Survey August-December, 2009

Garments workers were asked if the daily working hour prevailing in their respected factories is more than eight hours. $74 \%$ strongly agreed, whereas $20 \%$ agreed, and $6 \%$ were neutral in their comments. Therefore, about $94 \%$ agreed with this statement. 
Figure 4: Whether Employees are working More than Eight Hours

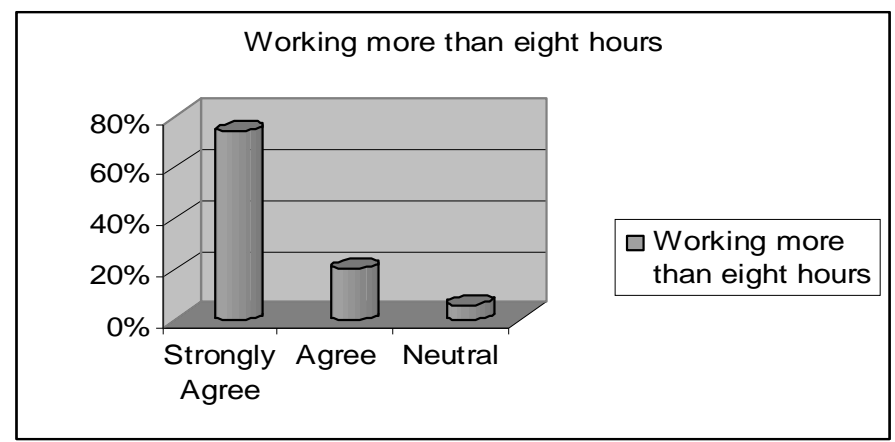

Source: Field Survey August-December, 2009

Out of 70 garments workers $14 \%$ demonstrated neutrally whether the overtime payment rate is twice as much as the normal payment rated, $17 \%$ disagreed, whereas $69 \%$ strongly disagreed. Therefore, about $86 \%$ disagreed with this statement. So, it is clear that most of the companies do not follow appropriate overtime payment system.

Figure 5: Whether Employees Overtime Payment Rate is Double of Normal Payment Rate

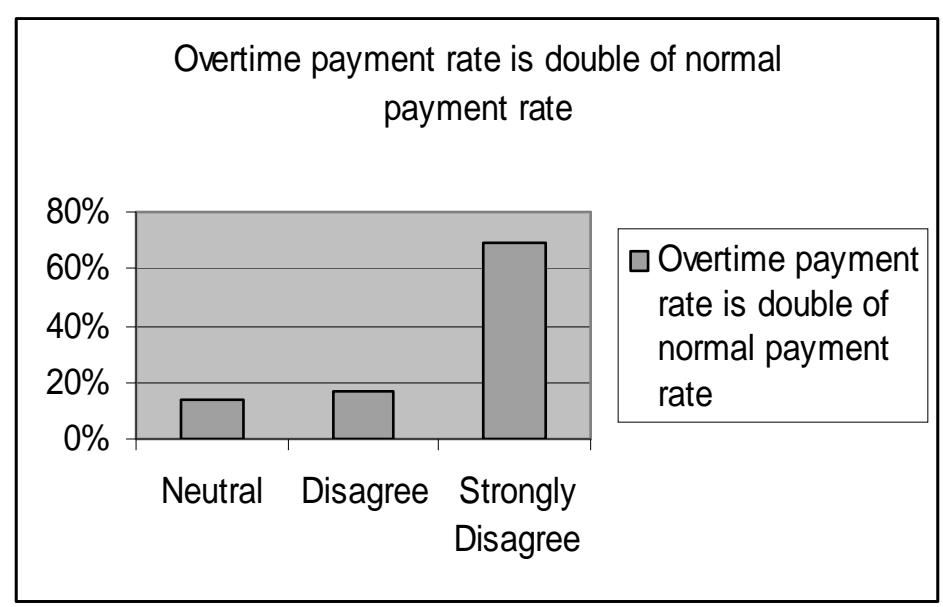

Source: Field Survey August-December, 2009

Garments workers were asked about their sick leave policy as per Bangladesh Labor Act 2006. 26\% employees disagreed that they did not get 14 days' sick leave with pay whereas $74 \%$ strongly disagreed with this statement. 
Figure 6: Whether the Company Gives Annually 14 Days Sick Leave with Pay

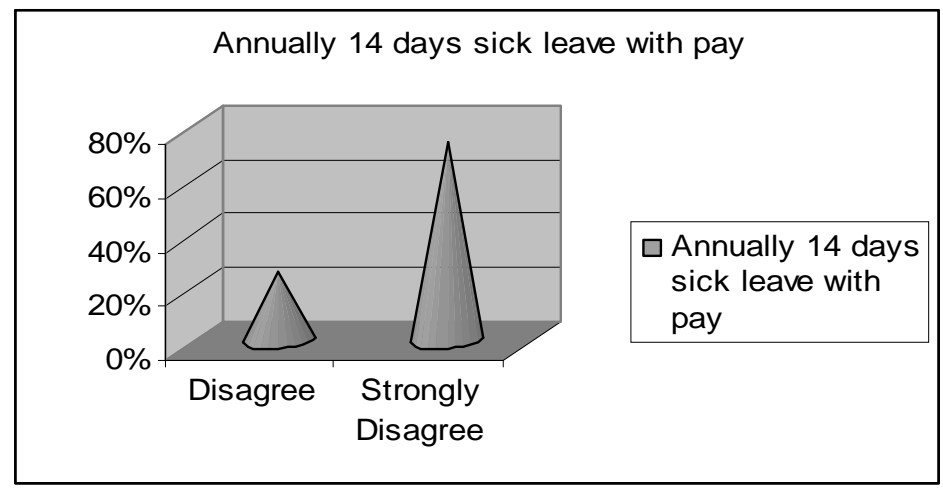

Source: Field Survey August-December, 2009

Garments workers were asked whether salary is paid within seven working days after completion of a month. 14\% agreed, whereas $17 \%$ disagreed, and $69 \%$ strongly disagreed in their comments. Therefore about $86 \%$ disagreed with this statement.

Figure 7: Whether Salary is paid Within Seven Working Days after Completion of One Month

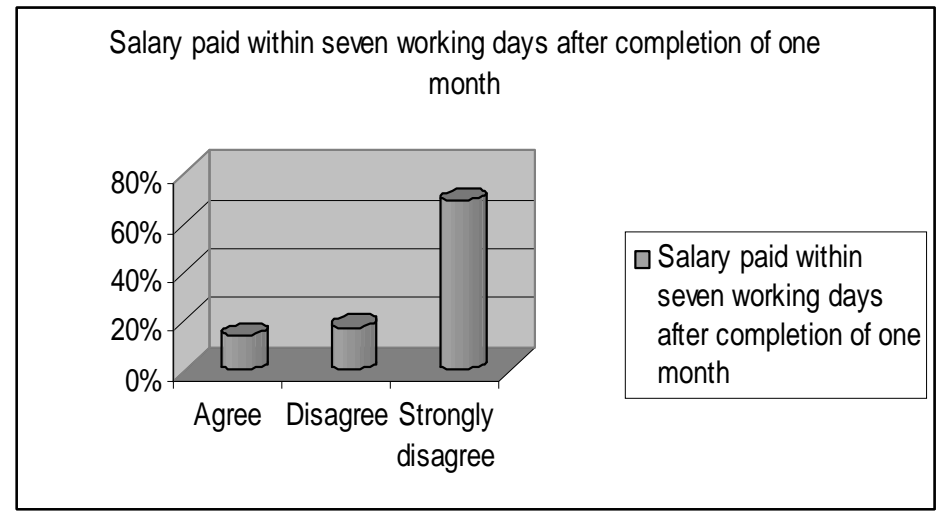

Source: Field Survey August-December, 2009

The author also asked whether salary is paid as per wage board declared salary and it was found that $8 \%$ were neutral, $54 \%$ disagreed whereas $37 \%$ strongly disagreed in their comments. If salary is paid as per wage board declared salary, workers are less likely to be dissatisfied with their job. 
Figure 8: Whether salary is paid as per wage board declared salary

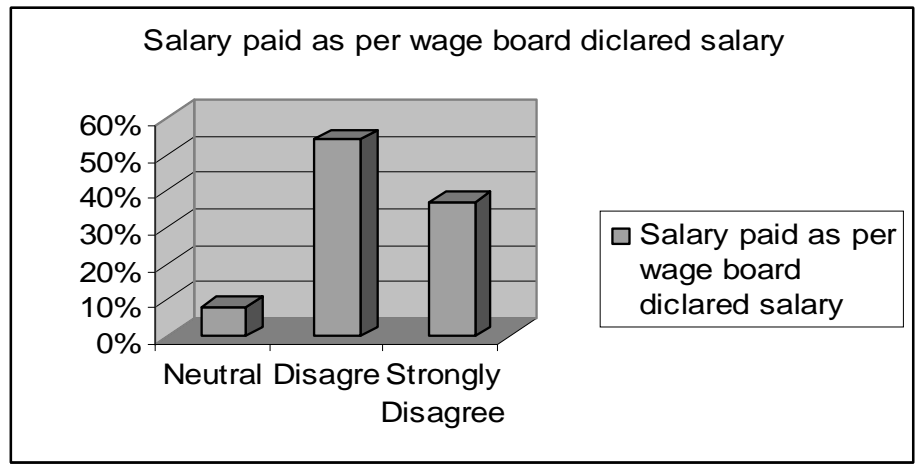

Source: Field Survey August-December, 2009

The workers of the garments factories expressed their opinion on amount of taka they received as salary. $16 \%$ respondents were neutral, $60 \%$ disagreed whereas $24 \%$ strongly disagreed in their opinions. Employees are eager to receive higher amount of salary but they are sometimes paid less than the wage board salary. Besides, the wage board salary was made in 2006 which is not appropriate for 2010.

Figure 9: Whether Employees Received Taka As Salary Is Satisfactory

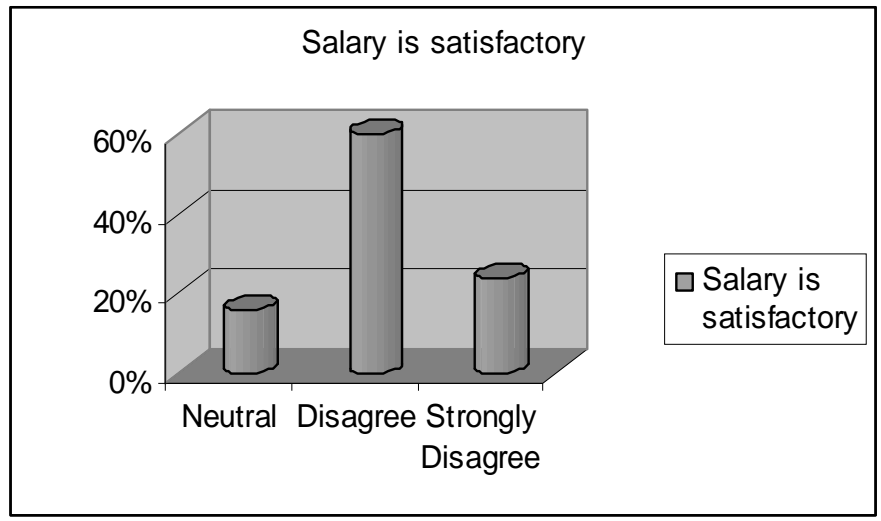

Source: Field Survey August-December, 2009

Employees were asked about the participatory fund and welfare fund and it was found that $14 \%$ disagreed with this statement and $86 \%$ strongly disagreed. So, all respondents said that there was no participatory fund and welfare fund for them. But these funds make the workers more loyal and committed to the organization. 
Figure 10: Whether There is Any Participatory Fund and Welfare Fund for the Employees

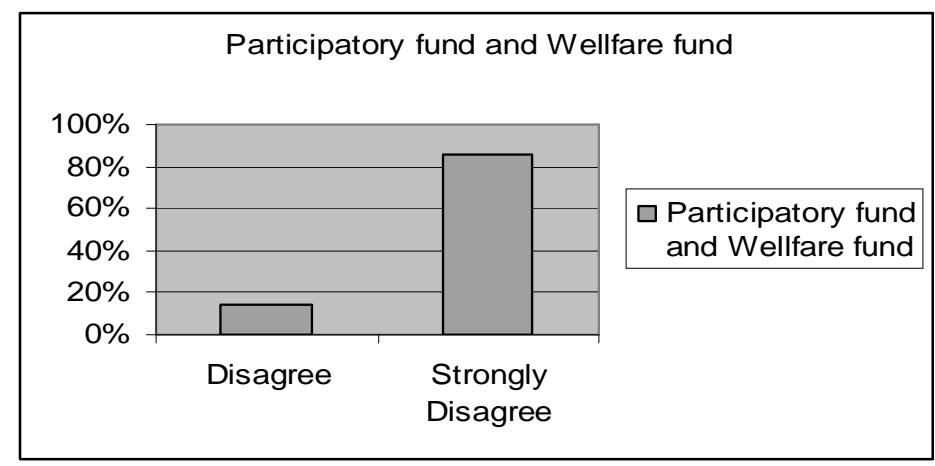

Source: Field Survey August-December, 2009

The workers of the garments factories expressed their opinions about management treatments to them. 54\% respondents expressed that they were neutral and $46 \%$ disagreed that owners listen to employees' complains and problems with importance.

Figure 11: Whether Management Listen Employees' Complains and Problems with Importance

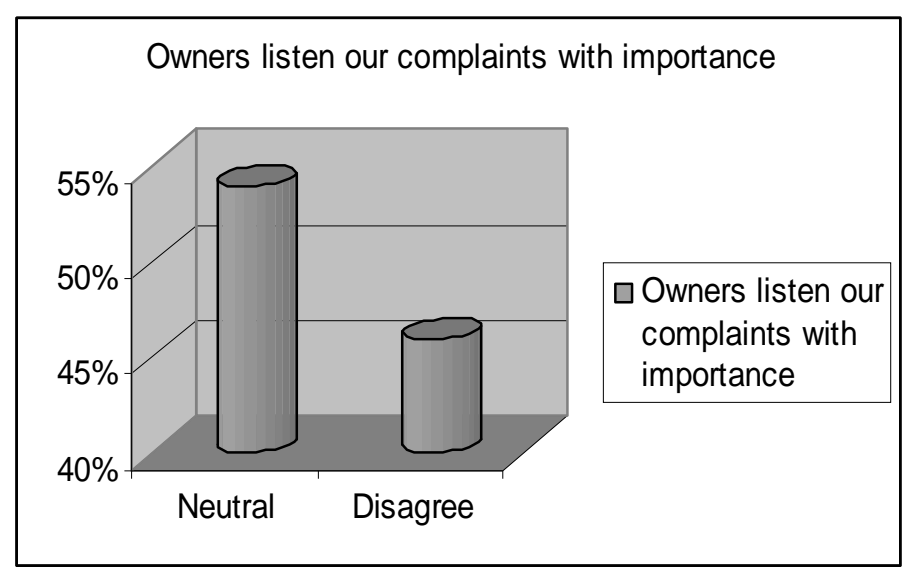

Source: Field Survey August-December, 2009

At last, workers were asked if they are satisfied with the overall condition of the company and it was found that $17 \%$ agreed with this statement, $57 \%$ were neutral and $26 \%$ disagreed in their opinion. 
Figure 12: Whether Employees are Satisfied with the Overall Condition of the Company

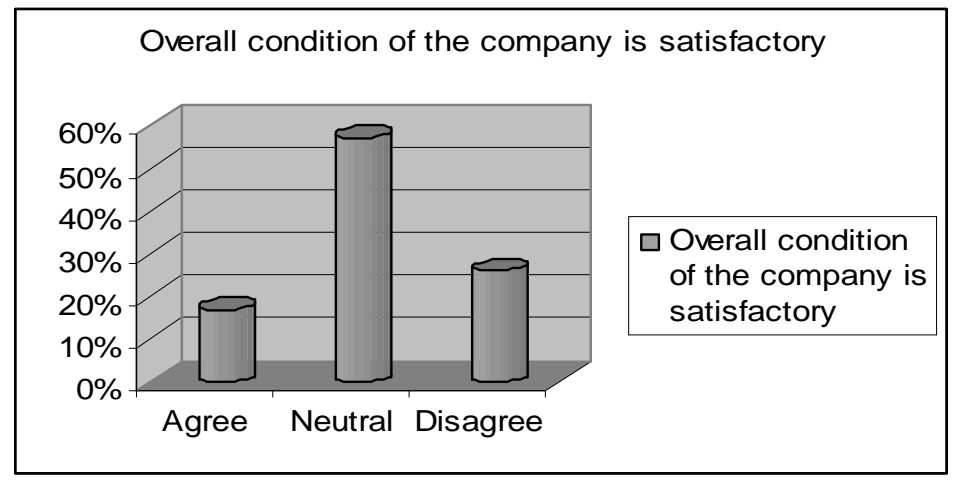

Source: Field Survey August-December, 2009

\section{Regression Analysis}

TABLE 3

REGRESSION ANALYSIS

\begin{tabular}{c|c|c|c|c}
\hline Model & R & R Square & Adjusted R Square & $\begin{array}{c}\text { Std. Error of the } \\
\text { Estimate }\end{array}$ \\
\hline 1 & $.715(\mathrm{a})$ & .511 & .456 & .03397 \\
\hline
\end{tabular}

Source: Field Survey August-December, 2009

From the above calculation it shows that there was a significant correlation between dependent variable and independent variables. And at 5\% level of significance the correlation is $71.50 \%$. Here, adjusted R Square is 0.456 which means that about 45.60 percent variation of dependent variable is explained by independent variables included in this model. And the independent variables of this model are service and employment, health and hygiene, safety and health, working hours and leave, wages and payment, trade unions and industrial relations (management and worker relations), and penalty and procedure.

TABLE 4

ANOVA TEST

\begin{tabular}{cl|c|c|c|c|c}
\hline & Model & $\begin{array}{c}\text { Sum of } \\
\text { Squares }\end{array}$ & df & $\begin{array}{c}\text { Mean } \\
\text { Square }\end{array}$ & F & Sig. \\
\hline $1 \quad$ Regression & .075 & 7 & .011 & 9.255 & $.000(\mathrm{a})$ \\
& Residual & .072 & 62 & .001 & & \\
\multicolumn{2}{c}{ Total } & .146 & 69 & & & \\
\hline \multicolumn{7}{l}{ Source: Field Survey August-December, 2009 }
\end{tabular}

Source: Field Survey August-December, 2009 
From ANOVA test it is revealed that the Table significance value 0.05 is greater than the calculated singnature. Value 0.000 . So, it rejects the null hypothesis at $5 \%$ level of significance and also $1 \%$ level of significance. It means there is a significant relation between dependent variable and independent variables. Therefore, labor unrest depends on proper implementation of Bangladesh labor Act 2006 in different garments factories in Bangladesh. But it does not mean that all elements of Bangladesh labor Act 2006 have significant impact on labor unrest. For this, the authors went for coefficient analysis for further study.

TABLE 5

\section{RESULTS OF MULTIVARIATE (OLS) ANALYSIS: LABOR UNREST (DEPENDENT VARIABLE), VIS-À-VIS PROPER IMPLEMENTATION OF BANGLADESH LABOR ACT, 2006 (INDEPENDENT VARIABLES)}

\begin{tabular}{|c|c|c|c|c|c|}
\hline \multirow[t]{2}{*}{$\begin{array}{c}\text { Different elements of } \\
\text { Bangladesh labor Act, } 2006\end{array}$} & \multicolumn{2}{|c|}{$\begin{array}{l}\text { Unstandardized } \\
\text { Coefficients }\end{array}$} & \multirow{2}{*}{$\begin{array}{c}\text { Standardized } \\
\text { Coefficients } \\
\text { Beta }\end{array}$} & \multirow[t]{2}{*}{$\begin{array}{l}\text { Estimated } \\
\text { t-value }\end{array}$} & \multirow[t]{2}{*}{$\begin{array}{l}\text { Significance } \\
\text { level }\end{array}$} \\
\hline & B & $\begin{array}{l}\text { Std. } \\
\text { Error }\end{array}$ & & & \\
\hline i) Service and employment & .003 & .099 & .007 & .028 & .978 \\
\hline ii) Health and hygiene & -.008 & .100 & -.015 & -.084 & .933 \\
\hline iii) Safety & -.080 & .103 & -.092 & -.772 & .443 \\
\hline iv) Working hours and leave & -.273 & .121 & -.255 & -2.250 & .028 \\
\hline v) Wages and payment & -.416 & .127 & -.457 & -3.278 & .002 \\
\hline $\begin{array}{l}\text { vi) Trade union and } \\
\text { industrial relations }\end{array}$ & -.407 & .160 & -.269 & -2.540 & .014 \\
\hline vii) Penalty and procedure & .072 & .192 & .057 & .378 & .707 \\
\hline
\end{tabular}

Source: Field SurveyAugust-December, 2009

Coefficient analysis shows the relationship between dependent variable and each independent variable. According to significance value workers' wages and payment, working hours and leave, and trade union and industrial relations (management and worker relations) have significant influence on labor unrest. Here, Table significnace value is 0.05 which is greater than calculated significnace value of $0.002,0.014$, and 0.028 respectively.

Service and employment and penalty and procedures shows positive values confirming the Pearson correlation results that service and employment and penalty and procedures have no negative relationship with dependent variable.

But the calculated significnace values of health and hygiene and safety and 
health are greater than the Table significnace value. And then, these factors have some impact on labor unrest but these are not significant.

\section{Summary of Findings}

At last final model includes five independent variables i.e., workers' wages and payment, working hours and leave, management and worker relations, safety and health and employer and worker relations which have significant impact on labor unrest.

Here,

$\beta 1$ (Wages and payment $)=-0.457$, i.e., $100 \%$ change in wages and payment leads to $45.70 \%$ reduction in labor unrest.

$B 2$ (Trade union and industrial relations $)=-0.269$, i.e., $100 \%$ positive change in trade union and industrial relation leads to $34.30 \%$ trim down in labor unrest.

$\beta 3$ (Working hours and leave $)=-0.255$, i.e., $100 \%$ change in working hour and leave leads to $25.50 \%$ decrease in labor unrest.

$B 4$ (Safety and health) $=-.092$, i.e., $100 \%$ improvement in safety and health measures leads to $9.20 \%$ reduction in labor unrest.

$B 5$ (Health and hygiene $)=-.015$, i.e., $100 \%$ improvement in health and hygiene measures leads to $1.50 \%$ reduction in labor unrest.

According to significant correlation, between dependent variables and each independent variable, we can arrange it in accordance to a descending order from most significant correlation to less significant correlation.

TABLE 6

DEPENDENCY OF LABOR UNREST ON PROPER IMPLEMENTATION OF BANGLADESH LABOR ACT, 2006

\begin{tabular}{ll|l}
\hline \multicolumn{1}{c|}{ Elements } & Value of $[\beta]$ & $\begin{array}{l}\text { Rank order on the basis } \\
\text { of standard coefficients }\end{array}$ \\
\hline Wages and payment & 0.457 & 1 \\
Trade union and industrial relations & 0.269 & 2 \\
Working hour and leave policy & 0.255 & 3 \\
Safety and health & 0.092 & 4 \\
Health and hygiene & 0.015 & 5 \\
\hline
\end{tabular}

Source: Field SurveyAugust-December, 2009 


\section{CONCLUSIONS}

In this study, seven major factors of the Bangladesh labor Act 2006 were taken into consideration. The study reveals that the most significantly related factor of labor unrest is the wages and payment. Most of the workers feel that they are not paid even as per wage commission declared pay. It is also not paid within the stipulated time that is within seven days of the following month. The workers felt that the factories they work for don't have any welfare fund for them. Industrial relation is the second most significant variable which contributes to labor unrest. Most of the workers feel that management does not listen to their complaints and problems. Absence of trade union makes it more difficult. Third significant factor is working hour and leave. They have to work more than eight hours a day but are not paid over time at double the rate of their pay as per the provision of the law. Most of the workers do not get sick leave as per law. Other factors that are service and employment conditions, health and hygiene, safety and penalty procedure are not significant factors for the workers. This may be because the workers are so much deprived and dissatisfied with their most important and basic needs that they are unable to think about other factors or higher level of needs. The data colleted reflect the views of workers of Gazipur area.

\section{REFERENCES}

Ahmed, Md. Nehal and Hossain Md. Sakhawat (2006) "Future Prospects of Bangladesh's Ready-Made Garments Industry and The Supportive Policy Regime”, Policy Note Series: PN 0702. Policy Analysis Unit (PAU), Research Department, Bangladesh Bank, Dhaka, Bangladesh.

Ahmed Abu, (2006) 'Form Regulatory Commission to Monitor RMG sector', The Daily Star, $27^{\text {th }}$ May, Dhaka.

Anonymous, (2003). 'Gold and Silver Employee Satisfaction Survey Programs'.

The Business Research Lab, LLC. http://www.busreslab.com. Accessed September, 20, 2009

Bangladesh Bureau of Statistics, (2007), Statistical Pocketbook of Bangladesh 2004, Planning Division, Ministry of Planning, Government of Bangladesh, Dhaka.

Choudhury Anwar, 2006, 'Proper CSR Practice Can Eliminate RMG unrest' The Daily Star, ${ }^{\text {rd }}$ November, Dhaka.

Government of Bangladesh, (2006), 'Bangladesh Labour Act, 2006' Bangladesh Gazette, October 11, 206, Dhaka.

Huq. S.A. (2009), Bangladesh labor Act, 2006, $1^{\text {st }}$ edition, Kalpana publishers, Dhaka-1221, section-3-9, 51-59, 61-72, 100-118, 120-126, 175-192, 283-307. 
Luthans, F., (2002) Organizational Behavior, $\left(9^{\text {th }}\right.$ ed) New York: McGraw-Hill International Companies Inc.

Mondol, Abdul Hye, (2003) "Impact of Globalization on Business, Industry and Workers in Bangladesh: Challenges and opportunities," Bangladesh Institute of Labor Studies (BILS), Dhaka.

Morshed, M Monjur (2007) "A Study on Labor Rights and Implementation in Readymade Garment Industry in Bangladesh: Bridging the Gap between Theory and Practice",

Rahman Elyus, (2006) "RMG worker's Rights: Law a Reality", The Daily Star, $3^{\text {rd }}$ June, Dhaka.

Rashid Mamunur, 2007, 'We Need to Take Care of Our Garments Sector' The Daily star, $27^{\text {th }}$ September, 2007, Dhaka.

The Daily Star, Dhaka, news reports titled.

'AL blames Minister, lingering discontent for garment unrest,' The Daily Star, $27^{\text {th }}$ May, 2006.

Agitation for Arrears, workers vandalizes 15 RMG factories, The Daily Star, $11^{\text {th }}$ August, 2008.

'Labor unrest, political tensions upset RMG buyers', The Daily Star, $3^{\text {rd }}$ November, 2006.

'Major RMG Fires Science 1990' The Daily Star, February, 27, 2010

'Poor Pay, Arrears, Garment workers unrest flares up again factories ransacked, officials assaulted at Gazipur, Savar,' The Daily star, $2^{\text {nd }}$ June, 2006.

'Tight security reins back workers' rage: Demonstrators still damage 5 Gazipur units; tripartite meeting decides to form Wage Commission' The Daily Star, $25^{\text {th }}$ May, 2006

World Bank, (2006), Bangladesh End of MFA Quotas: Key Issues and Strategic Options for Bangladesh Readymade Garment Industry, Report No. 34964-BD Poverty Reduction and Economic Management Sector Unit, South Asia Region. 